\title{
Effects of gamma radiation on microbial, physicochemical, and structural properties of whey protein model system
}

\author{
X. B. Wang, ${ }^{* 1}$ C. N. Wang, ${ }^{* 1}$ Y. C. Zhang, † T. T. Liu,† J. P. Lv, $\ddagger$ X. Shen,§ and M. R. Guo* ${ }^{*}$ \\ ${ }^{*}$ College of Food Science, Northeast Agriculture University, Harbin 150030, China \\ †College of Agriculture and Life Sciences, The University of Vermont, Burlington 05405 \\ łInstitute of Food Science and Technology, Chinese Academy of Agricultural Sciences, Beijing 100193, China \\ $\S$ College of Food Science and Engineering, Jilin University, Changchun, Jilin 130062, China
}

\begin{abstract}
Gamma radiation has been used in food processing for many years, though it has certain effects on food components. Whey protein solutions $(10 \% / 30 \%$, wt/ vol) were treated with gamma radiation at various dosages (10-25 kGy) and evaluated for microbial changes in the solutions and physicochemical and structural changes of whey proteins. Whey protein solutions after gamma radiation showed substantially lower populations of all viable microorganisms than those of controls. The $10 \%$ whey protein solution treated at radiation of 20 or $25 \mathrm{kGy}$ remained sterile for up to $4 \mathrm{wk}$ at room temperature. Gamma radiation increased viscosity and turbidity and decreased soluble nitrogen of whey protein solutions compared to nonradiated control samples regardless of radiation dosage. Nonreducing sodium dodecyl sulfate-PAGE suggested that whey proteins under gamma radiation treatment formed aggregates with high molecular weights. Reducing sodium dodecyl sulfate-PAGE showed that disulfide bonds played a role in gamma radiation-induced whey protein cross-linking. Scanning and transmission electron microscopy micrographs exhibited large aggregates of whey proteins after gamma radiation treatment. Results suggested that gamma radiation could be applied to whey protein solution for purposes of reducing microbial counts and cross-linking protein molecules.
\end{abstract}

Key words: gamma radiation, whey protein, physicochemical property, structural property

\section{INTRODUCTION}

Nonthermal processing technologies, such as ultrasonic (Foegeding et al., 2002; Shen et al., 2017), high-

Received November 2, 2017

Accepted January 26, 2018.

${ }^{1}$ These authors are contributed equally to this study.

${ }^{2}$ Corresponding author: mguo@uvm.edu pressure (Camp et al., 1997; Keim and Hinrichs, 2004), enzymatic (Ju et al., 1997; Ju and Kilara, 1998), and gamma radiation (Chawla et al., 2009), have generated much attention in food industry. In particular, the use of gamma radiation has drawn special attention due to the dual effects for both inhibiting microorganisms and altering structure of molecules by targeted processes. Gamma radiation has been proven to be an effective and safe method for sterilization of certain products. A wide variety of perishable food products (meat, fruits, and so on) are submitted to gamma radiation for preservation to control food-borne pathogens and reduce microbial load and insect infestation, thereby extending shelf life (Oliveira et al., 2007; Kasera et al., 2012). Gamma radiation can penetrate the products and eliminate microorganisms present in crevices and creases effectively (Prakash et al., 2010). Low-dosage gamma radiation has been accepted as neither presenting any toxicological hazard nor introducing any special nutritional or microbiological problems, thus being safe for human consumption (Tsiotsias et al., 2002). The Joint FAO/IAEA/WHO Expert Committee concluded in 1980 "that the gamma radiation of any food commodity up to an overall average dosage of $10 \mathrm{kGy}$ presents no toxicological hazard" (FAO/IAEA/WHO, 1980).

Gamma radiation may induce changes in the molecular characteristics of components in foods at certain dosages. Foods or an ingredient have been treated by gamma radiation to ensure a change for facilitated processing purposes (Sabato and Lacroix, 2002; Cieśla et al., 2004). Gamma radiation generates direct or indirect effects to foods in a dry or aqueous state, respectively. For solid foods, molecules absorb radiation energy directly and result in changes in the structure of food components. Aqueous solutions in water first exposed to gamma radiation generate hydroxyl radicals and hydrated electrons, which can in turn react with molecules to form covalent bonds (Oliveira et al., 2007). Radiation treatment is known to affect protein molecules (Silva et al., 2006); it can affect proteins by causing conformational changes (Mcparland, 2010) and 
promoting reactions such as oxidation of AA, cleavage of peptide, and formation of disulfide bonds by association of aromatic and heterocyclic residues (Abu et al., 2006). Gamma radiation has been employed to improve water vapor permeability and chemical stability of protein-based films (Ouattara et al., 2002), mechanical resistance of milk protein gels (Cieśla et al., 2004), viscosity of whey dispersions (Atlay and Alfred, 2004), oil absorption, and emulsion capacities of cowpea protein isolates (Abu et al., 2006). In addition, gamma radiation was shown to have reduced the allergenicity of different allergenic foods by structurally altering the human IgE-binding epitopes in food allergens (Lee et al., 2001).

Whey is an abundant by-product of cheesemaking. Whey proteins, enriched protein fractions from whey, have various functional properties, including emulsifying, gelation, thickening, and water-holding capacities (Zhang et al., 2015). Whey proteins can be designed for enhanced functional properties by altering the protein structure through physical, chemical, or other means (Foegeding et al., 2002). The effects of gamma radiation on whey proteins were mostly limited to the edible film mechanical properties and allergenicity reduction. Furthermore, the effect of gamma radiation on microbiological properties of perishable food products such as meat and fruits has been studied with low dosages of gamma radiation. No information is available on the effects of gamma radiation on microbiological, physicochemical, and structural properties of whey protein solution. In the current study, the effects of gamma radiation on whey protein (10 and $30 \%$ solutions) at high dosages (10-25 kGy) were investigated for changes in microbiological and physicochemical properties as well as protein-protein interaction and microstructure.

\section{MATERIALS AND METHODS}

\section{Materials}

Whey protein isolate (WPI; 92\% protein, wt/wt) was purchased from Fonterra Co-operative Group (Auckland, New Zealand). The protein content was verified by Kjeldahl method (Standardization Administration of the People's Republic of China. 2016). Other components were (wt/wt) $0.36 \%$ fat, $1.6 \%$ ash, $0.7 \%$ lactose monohydrate, and $0.07 \%$ calcium. Aerobe, yeast, and mold count plates were 3M Petrifilm (3M, St. Paul, MN). Prefilled buffer $(9 \mathrm{~mL})$ was purchased from Fisher Scientific Inc. (Pittsburgh, PA). All other chemicals used were of reagent grade and purchased from Sigma-Aldrich Co. LLC (St. Louis, MO). Deionized water (resistivity was above 18.2 M $\Omega$ ) was obtained using a Milli-Q deionization reversed osmosis system (Millipore Corp., Bedford, MA).

\section{Gamma Radiation Treatment}

Whey protein solutions (10 and 30\%, wt/vol) were prepared by dissolving WPI powder slowly into deionized water at room temperature with the help of magnetic stirring $(500 \mathrm{rpm})$ for $2 \mathrm{~h}$ before storage at $4^{\circ} \mathrm{C}$ overnight to allow complete hydration. When calculating the amount of whey protein solutions to be added, a correction for the protein content of the powder was taken into account. The solutions remained at the original $\mathrm{pH}$ of approximately 6.8 . Gamma radiation treatment of WPI samples (each in 50-mL centrifuge tubes) were performed with a ${ }^{60} \mathrm{Co}$ irradiator (Gammacell 220, Nordion, Ottawa, Canada) at average dosages of 10 to $25 \mathrm{kGy}$ at ambient temperature with presence of oxygen. The Gammacell 220 operates on a $220 \mathrm{~V}, 60$ $\mathrm{Hz}$, and 15 A supply. Samples were then left at room temperature for up to $4 \mathrm{wk}$ and withdrawn periodically for microbial and physiochemical analysis. Untreated whey protein solutions stored under the same condition were used as controls.

\section{Microbial Analysis}

Each sample $(1 \mathrm{~mL})$ was diluted to gradient concentration by $10^{-1}, 10^{-2}$, and $10^{-3}$ with $9 \mathrm{~mL}$ of prefilled sterile buffer. Each dilution was applied on aerobe, yeast, and mold counts according to the manufacturer's instructions (3M Petrifilm; https://multimedia.3m.com/ mws/media/236194O/petrifilm-aerobic-interpretation -guide.pdf). The top of film was lifted to expose the surface and $1 \mathrm{~mL}$ of each dilution $\left(10^{-1}, 10^{-2}\right.$, and $\left.10^{-3}\right)$ from each sample was added inside a circular foam barrier on aerobe, yeast and mold count Petrifilms. After drying for 5 min, aerobe count Petrifilms were put into an incubator at $37^{\circ} \mathrm{C}$ for $48 \mathrm{~h}$, whereas yeast and mold count Petrifilms were incubated at $21^{\circ} \mathrm{C}$ for at least 48 h. The readable plate count was between 25 and $250 \mathrm{cfu}$ and the final data were expressed as $\log \mathrm{cfu} / \mathrm{mL}$, which was the logarithm to base 10 of the microorganism's population value per milliliter. Triplicates for each sample for 3 trials were tested.

\section{Viscosity Measurement}

Viscosity of whey protein solutions before and after gamma radiation at various dosages was determined at room temperature $\left(23 \pm 1^{\circ} \mathrm{C}\right)$ using a Brookfield Viscometer (model DV-I Prime, Brookfield Engineering Labs Inc., Stoughton, MA). Samples were tested with 
spindle \#3 at $100 \mathrm{rpm}$. The viscosity reading on the screen was recorded after the spindle has been activated for $20 \mathrm{~s}$. Three trials were performed for each sample and each sample in triplicates.

\section{Turbidity Determination}

Turbidity of whey protein solutions before and after gamma radiation was determined at room temperature $\left(23 \pm 1^{\circ} \mathrm{C}\right)$. Absorbance readings of samples were taken at $600 \mathrm{~nm}$ using a selected digital Genesys 10s UV-VIS Spectrophotometer (Thermo Scientific Inc., Pittsburgh, PA). Reported value was the average of 3 consecutive readings. Three trials were performed for each sample and each in triplicates.

\section{Soluble Nitrogen Measurement}

The $\mathrm{pH}$ 4.6-soluble nitrogen of whey protein solutions was tested according to the method of International Dairy Federation (IDF, 1964). Four milliliters of samples were weighed and added into 10-mL centrifuge tubes. Deionized water at equivalent volumes with samples was transferred into each tube. Acetic acid $(10 \% \mathrm{vol} / \mathrm{vol}, 0.4 \mathrm{~mL})$ was added to each tube, mixed, and maintained for $10 \mathrm{~min}$ followed by adding $0.4 \mathrm{~mL}$ sodium acetate $(1 M)$ and then mixed gently. All tubes were filled to $10 \mathrm{~mL}$ with deionized water. The mixture was filtered through Fisher Q 8 filter paper (Pittsburgh, PA). The filtrate was taken for nitrogen determination by Kjeldahl method. Three trials were performed for each sample and each was in triplicate.

\section{SDS-PAGE}

Radiated whey protein solutions and the controls were analyzed for protein profile using nonreducing and reducing SDS-PAGE. All samples were diluted to $1 \%$ (wt/vol) concentration with deionized water. For nonreducing conditions, a portion of $30-\mu \mathrm{L}$ diluted samples was mixed with $10 \mu \mathrm{L}$ of $4 \times$ loading buffer. The loading buffer was composed of $0.25 M$ Tris- $\mathrm{HCl}(\mathrm{pH}=$ 6.8 ), $50 \%$ (vol/vol) glycerol, and $0.5 \%$ (wt/vol) bromophenol blue. For reducing conditions, a $32-\mu \mathrm{L}$ volume of sample was weighed and then mixed with $8 \mu \mathrm{L}$ of $5 \times$ loading buffer. The loading buffer was similar with those for nonreducing conditions but incorporated $10 \%$ (wt/vol) SDS and 7.8\% (wt/vol) DL-dithiothreitol. The assayed sample and loading buffer were mixed in 1.5$\mathrm{mL}$ Eppendorf tubes and sealed. The tubes were placed in boiling water for 3 to $5 \mathrm{~min}$ and then immediately cooled on ice. The SDS-PAGE was conducted with $12 \%$ separating gel and $4 \%$ stacking gel according to the method of Guo (1995); voltage was increased from 80 to $120 \mathrm{~V}$. After electrophoresis, the gels were stained with Coomassie blue fast staining solution for approximate $2 \mathrm{~h}$ and destained with deionized water. The protein ladder ranging from 10 to $170 \mathrm{kDa}$ (Thermo Scientific) was used as molecular weight standard.

\section{Microstructure Analysis}

Whey protein solutions at both concentrations after gamma radiation at 15 and $25 \mathrm{kGy}$ and control samples were analyzed for microstructure. Solutions were frozen in liquid nitrogen and then fractured. The pieces were mounted on aluminum stubs with silver conductive paste, carbon coated, and then sputter coated with $\mathrm{Au} / \mathrm{Pd}$ (approximate $4 \mathrm{~nm}$; Hendricks and Hadley, 1983). Samples were then scanned on a scanning electron microscope (FEI Quanta 200, Worcester, MA) at an accelerating electron voltage of 5 and $20 \mathrm{kV}$. Images were recorded digitally using Scandium software (Olympus, Tokyo, Japan). Samples in an aqueous state were directly submitted to a transmission electron microscope (JEOL 1400, Tokyo, Japan) at the University of Vermont.

\section{Statistical Analysis}

All experiments were performed in triplicates for 3 batches. We used SPSS Version 21 software for Linux (IBM Corp., Armonk, NY) for statistical analysis. The data were analyzed by 1-way ANOVA to analyze the effects of gamma radiation treatment and storage time. Significant differences between group means of the variations were observed in partitioned components. A $P$-value $<0.05$ was considered as significantly different.

\section{RESULTS AND DISCUSSION}

\section{Effects of Gamma Radiation on Microbial Properties of Whey Protein Solutions}

Gamma radiation proved to be effective in reducing microorganisms' contamination. Radiated microorganisms frequently retained metabolic activities and morphology but lost their reproductive ability (Demicheli et al., 2006). The reproductive ability of radiated cells was monitored by their capacity to form colonies in a Petrifilm.

Without gamma radiation, the populations of aerobic bacteria were too numerous to count and $6.3 \log \mathrm{cfu} /$ $\mathrm{mL}$ for 10 and $30 \%$ whey protein solution, respectively. When treated at dosages of 10 and $15 \mathrm{kGy}$, both solutions showed significantly decreased aerobic microbe 
population and remained a lower number in comparison with the control through the storage time. Gamma radiation decreased the population to below $2 \log \mathrm{cfu} /$ $\mathrm{mL}$ during the storage of $10 \%$ whey protein solution at levels of 20 and $25 \mathrm{kGy}$. Whey protein solutions at $30 \%$ concentration were radiated at 20 and $25 \mathrm{kGy}$ and the solutions almost gelled; thus, this treatment was discontinued for the analysis.

Yeasts are eukaryotic, single-celled microorganisms classified as members of the fungus kingdom; they can even grow during refrigeration $\left(4^{\circ} \mathrm{C}\right)$ and cause foods spoilage (Alighourchi et al., 2008). Microbial analysis revealed the yeasts populations of 3.3 and $4.6 \mathrm{log} \mathrm{cfu} /$ $\mathrm{mL}$ for 10 and $30 \%$ whey protein solutions, respectively. Gamma radiation decreased yeasts counts to as low as $2 \log \mathrm{cfu} / \mathrm{mL}$ in both whey protein solutions at the beginning, with a 1.3 to $2.6 \log$ reduction in comparison with controls. Both samples treated at 10 and $15 \mathrm{kGy}$ showed significantly lower populations than those of control samples at the same time point during storage, indicating the retarding effect of gamma radiation. Gamma radiation at 20 and $25 \mathrm{kGy}$ resulted in the yeast counts $\leq 2 \log \mathrm{cfu} / \mathrm{mL}$ for $10 \%$ solution through the storage.

The initial mold counts in 10 and $30 \%$ whey protein solutions were 3.5 and $3.7 \log \mathrm{cfu} / \mathrm{mL}$, respectively. Gamma radiation eliminated most of the molds in the aqueous samples at the beginning. Both whey protein solutions treated with 10 and $15 \mathrm{kGy}$ went through 1 $\log$ increase in the third and fourth weeks; however, they still lower than those of control samples. High radiation dosage at 20 and $25 \mathrm{kGy}$ resulted in counts $\leq 2$ $\log \mathrm{cfu} / \mathrm{mL}$ for $10 \%$ whey protein solution throughout the whole storage period.

\section{Effects of Gamma Radiation on Viscosity of Whey Protein Solutions}

Changes caused in viscosity by gamma radiation depend on factors such as dosage, $\mathrm{pH}$, hydration state, and temperature during gamma radiation (Abu et al., 2006). Data showed that gamma radiation under 10 kGy did not change the viscosity of proteins such as bovine blood plasma proteins (Lee et al., 2003). As no physicochemical properties or secondary structures changes were detected in low-dosage gamma-radiated protein samples (Lee et al., 2003; Agúndez-Arvizu et al., 2006), medium-level gamma radiation (average dosages of 10-25 kGy) was applied in our study. In an aqueous state, the medium (namely water) can absorb the gamma ray directly and the generated hydroxyl radical and superoxide anion then interact with protein and cause physical and chemical modifications, such as aggregation and cross-linking between proteins (Liu et al., 2009). Viscosity of nonradiated and radiated 10 and $30 \%$ whey protein solutions plotted against gamma radiation dosage and storage time is presented in Figure 1 . Whey protein solutions at $10 \%$ concentration after gamma radiation displayed significantly higher viscosity than that of control sample $(P<0.05)$ in the first week. Molecular aggregation may be responsible for this increase. In the first week, viscosity of samples increased as radiation level increased; however, no significant change was found for treated samples. During storage, viscosity of the control sample increased significantly $(P<0.05)$, which may have been caused by increased microorganisms. In the second and third weeks, the significant differences between control and samples treated at 10 to $20 \mathrm{kGy}$ disappeared. In the last week, the control sample showed significantly higher viscosity than samples treated at 10 to $20 \mathrm{kGy}(P<0.05)$, and we observed no significant difference between control and 25-kGy radiated samples $(P>0.05)$.

Compared with the control, $30 \%$ whey protein solution showed significantly higher viscosity throughout the storage period after treatment $(P<0.05)$. No significant difference was observed between radiated samples under 10 and $15 \mathrm{kGy}$ during storage; similar results were reported by Sabato and Lacroix (2002).

\section{Changes in Turbidity of Whey Protein Solutions After Gamma Radiation}

Turbidity changes of the whey protein solutions after gamma radiation are shown in Figure 2. Turbidity reflects the aggregation state of protein that remained suspended in the liquid. Whey protein samples (10\%) after gramma radiation showed significantly higher values than that of the control sample $(P<0.05)$ in the first week; however, this difference disappeared in the following 3 wk. Gamma radiation had more significant influence on turbidity of $30 \%$ whey protein solution than that of $10 \%$ solution. Whey protein samples $(30 \%)$ under gamma radiation at dosages of 10 and $15 \mathrm{kGy}$ exhibited almost 2-fold higher turbidity values than control samples in the first $3 \mathrm{wk}$. We found no significant difference between treated samples and control in the fourth storage week.

\section{Effects of Gamma Radiation on Soluble Nitrogen of Whey Protein Solutions}

Soluble nitrogen is influenced by various factors, such as protein denaturation, size, structure, and conformation, charges, AA composition, and sequence of the protein molecules (Zayas, 1997). Whey protein solution 

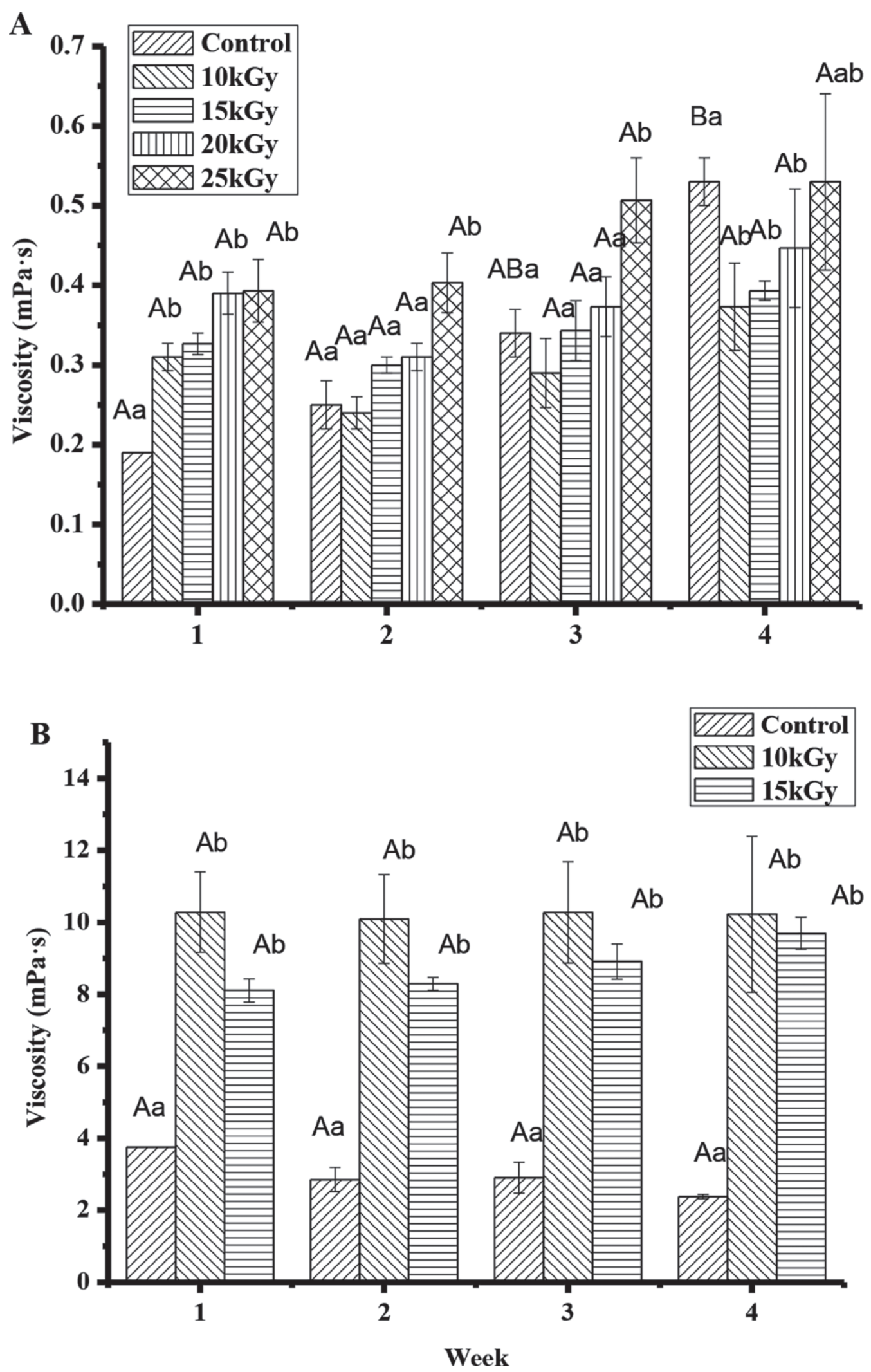

Figure 1. Changes in viscosity of $10(\mathrm{~A})$ and $30 \%$ (B) whey protein solutions after radiation during storage at room temperature. Different lowercase letters $(\mathrm{a}, \mathrm{b})$ denote significant difference between samples treated with various dosages at $P<0.05$; different uppercase letters $(\mathrm{A}, \mathrm{B}$ ) denote significant difference between samples at different storage times at $P<0.05$. Error bars are \pm SD of the means. 
WANG ET AL.
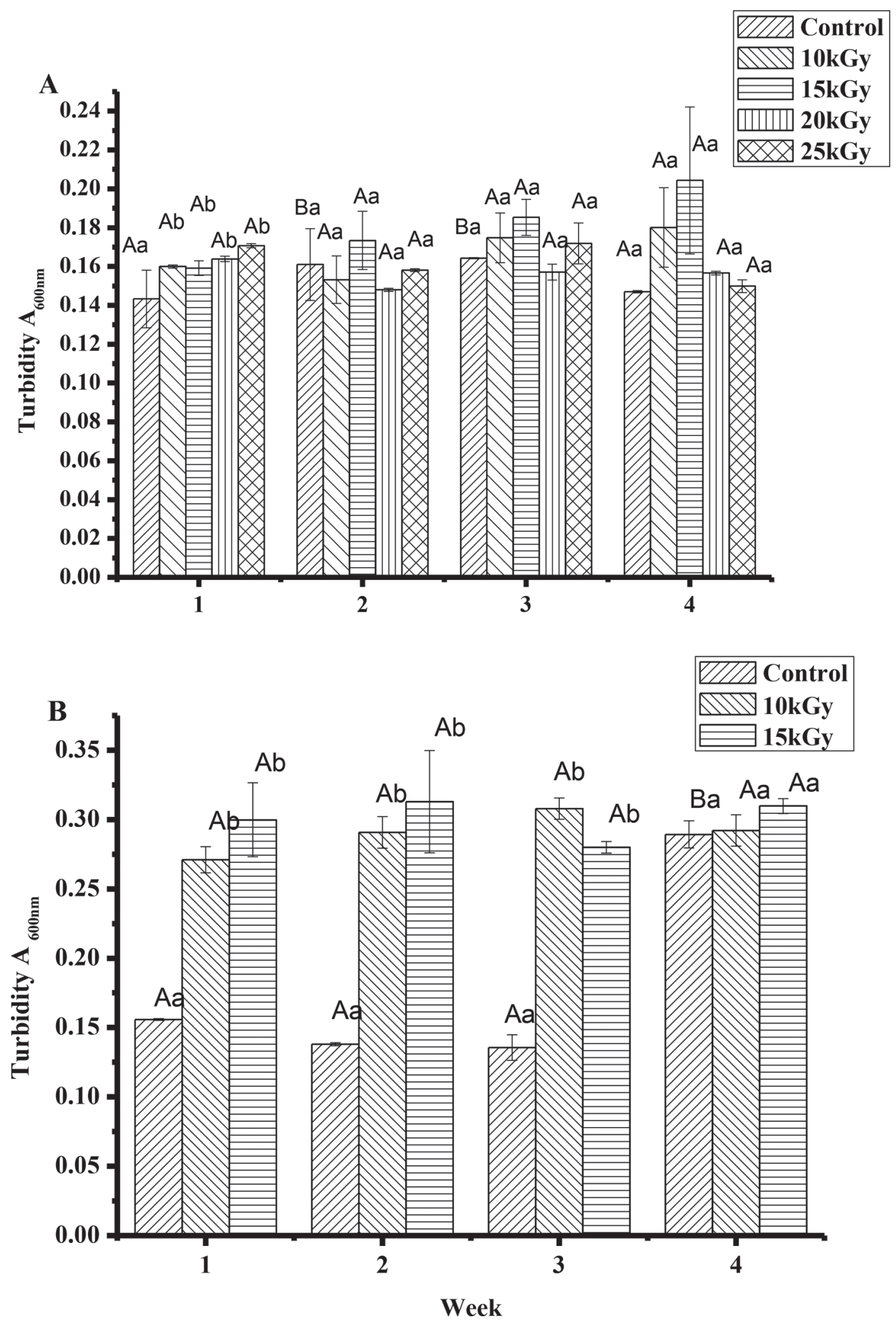

Figure 2. Changes in turbidity of 10 (A) and 30\% (B) whey protein solutions after radiation during storage at room temperature. Different lowercase letters $(\mathrm{a}, \mathrm{b})$ denote significant difference between samples treated with various dosages at $P<0.05$; different uppercase letters $(\mathrm{A}, \mathrm{B})$ denote significant difference between samples at different storage times at $P<0.05$. Error bars are \pm SD of the means. 


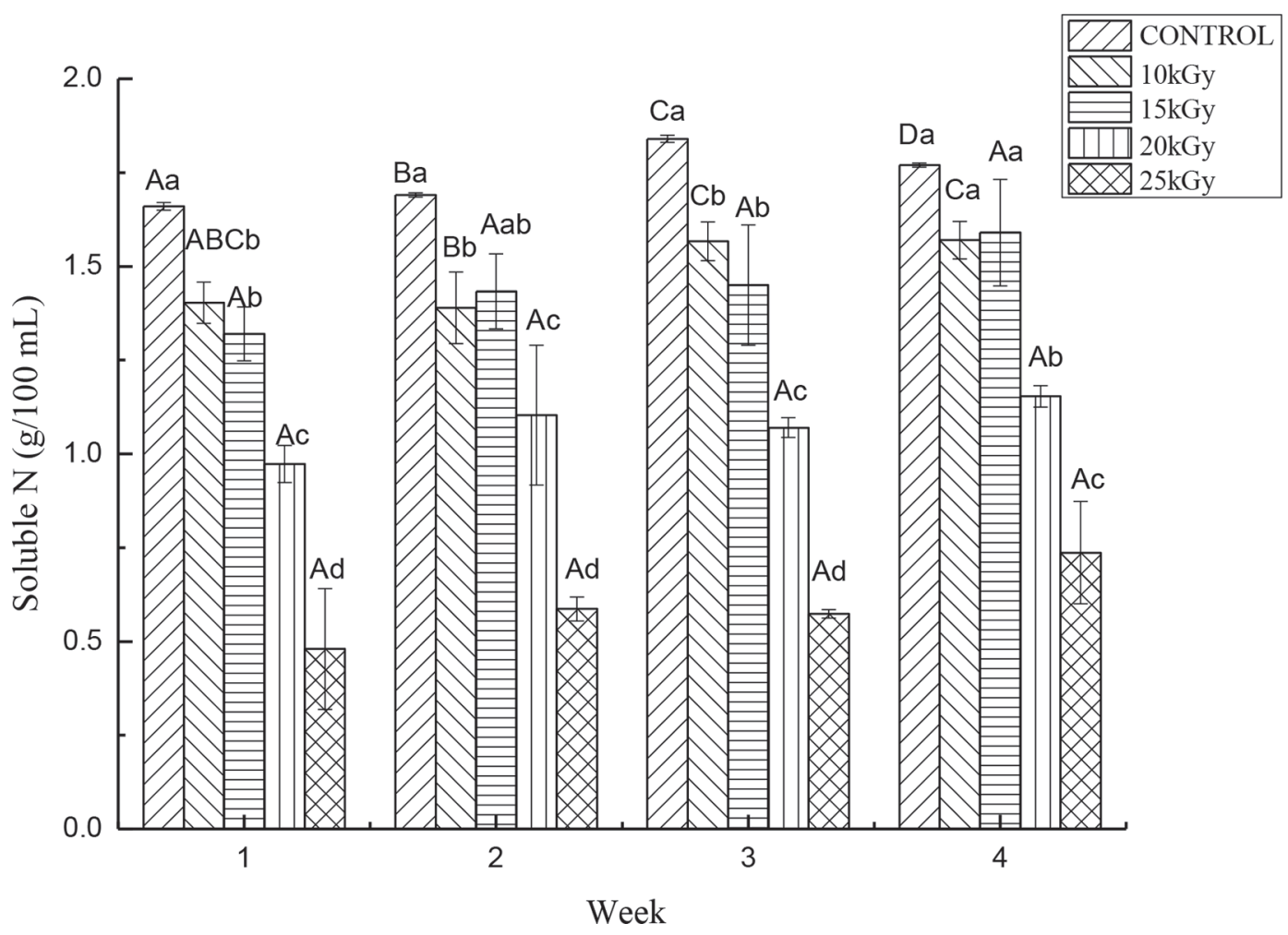

Figure 3. Changes in soluble nitrogen of $10 \%$ (wt/vol) whey protein solution after radiation during storage at room temperature. Different lowercase letters ( $\mathrm{a}-\mathrm{d}$ ) denote significant difference between samples treated with various dosages at $P<0.05$; different uppercase letters (A-D) denote significant difference between samples at different storage times at $P<0.05$. Error bars are \pm SD of the means.

at $10 \%$ concentration was chosen for the measurement of soluble nitrogen due to the feasibility of viscosity; results are shown in Figure 3. Structural modification of whey protein by gamma radiation decreased the solubility at $\mathrm{pH} 4.6$ of whey protein significantly $(P<$ $0.05)$. Soluble nitrogen content of samples was negatively related to the dosage applied. Increased hydrophobicity after denaturation or the altered isoelectric point due to aggregation may be responsible for the decreased solubility.

During storage, control samples exhibited a significant increase $(P<0.05)$ in solubility. Samples treated at the low dosage of $10 \mathrm{kGy}$ showed significant changes in soluble nitrogen as storage time processed $(P<0.05)$. It seemed that higher treatment dosage ensured the stability in soluble nitrogen, and no significant changes for samples treated above $15 \mathrm{kGy}$ were observed during storage $(P>0.05)$.

\section{Effects of Gamma Radiation on Protein Profile of Whey Protein}

Amino acids exposed to radiation may experience covalent cross-linking (Mezgheni et al., 1998). Both nonreducing and reducing SDS-PAGE were used to examine interactions between whey proteins after gamma radiation. Whey protein solutions under various dosages of radiation showed monomeric whey protein bands of $\beta$-LG, $\alpha$-LA, and BSA (Figure 4). Compared with control, new bands appeared at higher molecular weight ranges, indicating the aggregation of whey protein treated with gamma radiation; aromatic AA in whey protein may be responsible for the aggregation. Similar results were reported by Lee et al. (2000), who found the newly generated bands with higher molecular weight for myosin after radiation treatment. The formation of aggregates with high molecular weight was negligible at low dosage, but increased considerably at higher dosage up to $20 \mathrm{kGy}$ for $10 \%$ whey protein solution. We noted protein-like material at the top of $\mathrm{E}$ and F lanes (10\% WPI treated at 20 and 25 kGy; Figure 4), which maybe protein aggregates that were too large to enter the gel. Similar results were reported by Schokker et al. (1999), who also detected the aggregates not entering the stacking gel when whey protein was heated at $78.5^{\circ} \mathrm{C}$. Oliveira et al. (2007) reported that the sizes of oligomers were proportional to the radiation dosages and inversely proportional to protein concentrations. 
As expected, $30 \%$ samples showed light bands at higher molecular weight ranges compared with $10 \%$ whey protein solution.
Inter- and intramolecular disulfide bonds were the main force responsible for the aggregates of whey protein (Havea et al., 2004). A thiol blocker was used to
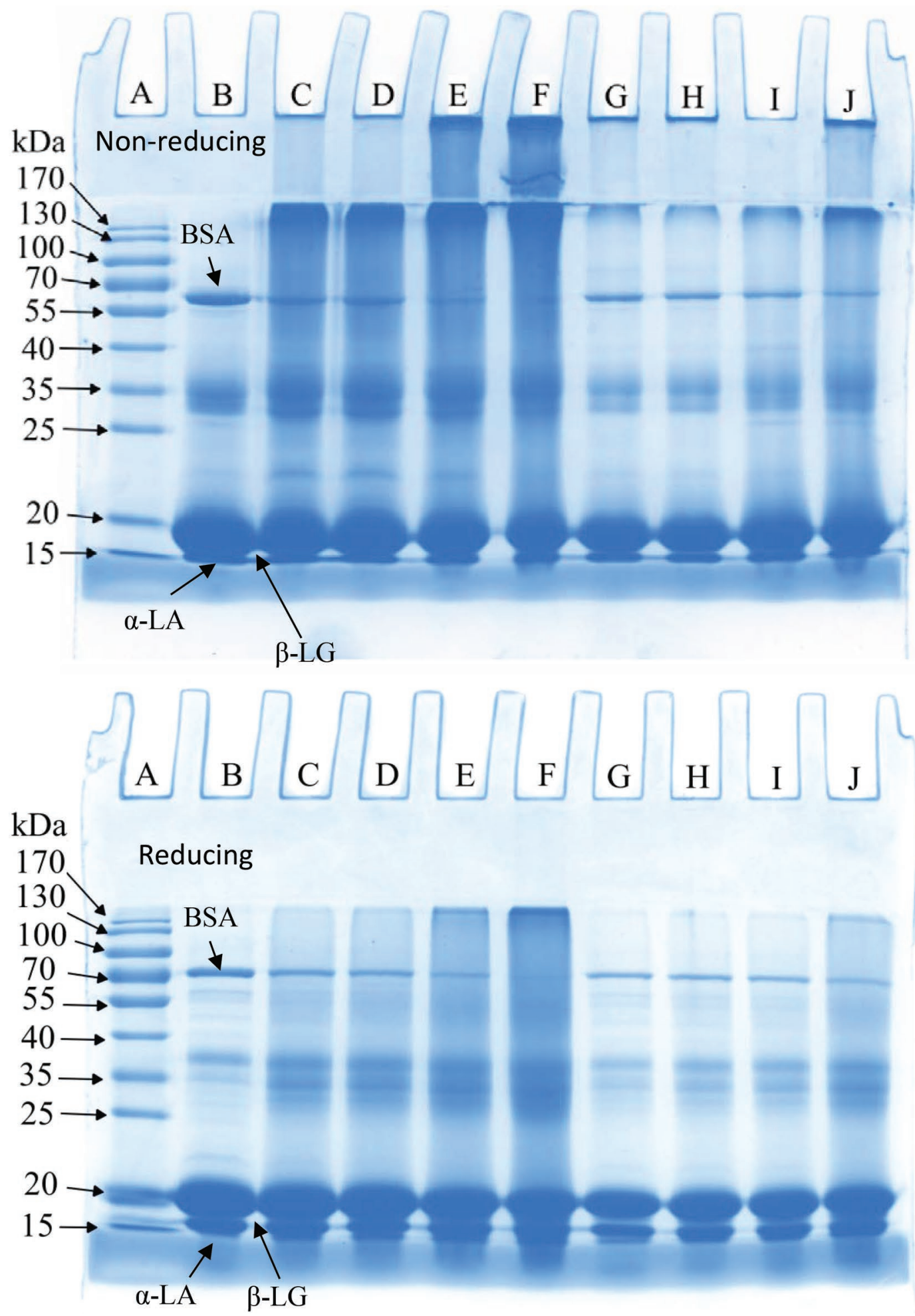

Figure 4. Nonreducing and reducing SDS-PAGE photographs of control and radiated whey proteins. A: marker; B: control; C: 10\% whey protein solution (WPS), 10 kGy; D: 10\% WPS, 15 kGy; E: 10\% WPS, 20 kGy; F: 10\% WPS, 25 kGy; G: 30\% WPS, 10 kGy; H: $30 \%$ WPS, 15 kGy; I: 30\% WPS, 20 kGy; J: 30\% WPS, 25 kGy. Color version available online. 
study the role of disulfide bonds in the aggregation of whey protein molecules after gamma radiation treatment. Dithiothreitol is a powerful reducing agent, and it would cleave the disulfide bonds within the protein molecules as well as any intermolecular disulfide bonds. Reducing SDS-PAGE photos of radiated samples showed light bands in the high molecule regions, indicating the role of disulfide bonds in the aggregation of whey protein molecules induced by gamma radiation.
Compared with control samples, more intense bands in the range of 25 to $40 \mathrm{kDa}$ indicated the aggregates with medium size induced by gamma radiation. It should be known that $\beta$-LG existed in solution as a dimer at a $\mathrm{pH}$ between 3 and 7 and the molecular weight should be $36 \mathrm{kDa}$ (Chatterton et al., 2006). Reducing SDS-PAGE seemed to suggest that disulfide bonds played a role in the cross-linking of whey proteins; similar results were observed for cowpea protein (Abu et al., 2006).

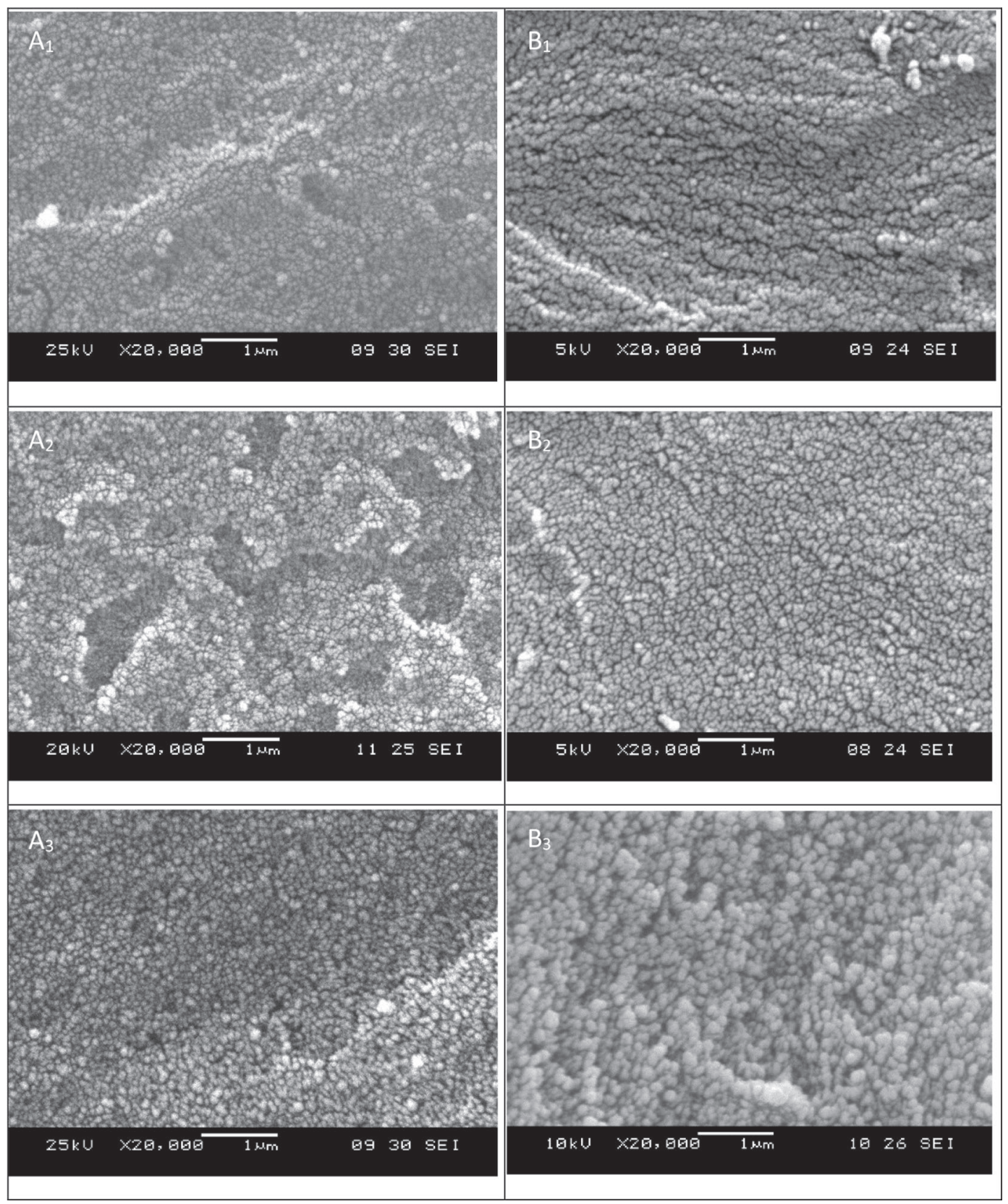

Figure 5. Scanning electron microscopy micrographs of control and radiated whey protein. $\mathrm{A}_{1}=10 \%$ whey protein solution (WPS), control; $\mathrm{A}_{2}: 10 \%$ WPS, $15 \mathrm{kGy} ; \mathrm{A}_{3}: 10 \%$ WPS, $25 \mathrm{kGy}$; $\mathrm{B}_{1}: 30 \%$ WPS, control; $\mathrm{B}_{2}: 30 \%$ WPS, $15 \mathrm{kGy} ; \mathrm{B}_{3}: 30 \%$ WPS, $25 \mathrm{kGy}$. 


\section{Microstructure Changes of Whey Protein After Gamma Radiation}

Microstructure for whey protein (10 and 30\%, wt/ vol) control and treated samples were examined by scanning and transmission electronic microscopy. The micrographs of whey protein samples are shown in Figures 5 and 6. Five microstructural parameters, including porosity, clusters, conglomerates, strings of aggregates, and hairiness, are usually used to describe protein microstructure (Langton and Hermansson, 1996). The microstructure of whey protein was altered by gamma radiation at various dosages. The scanning electron microscopy micrographs showed that whey

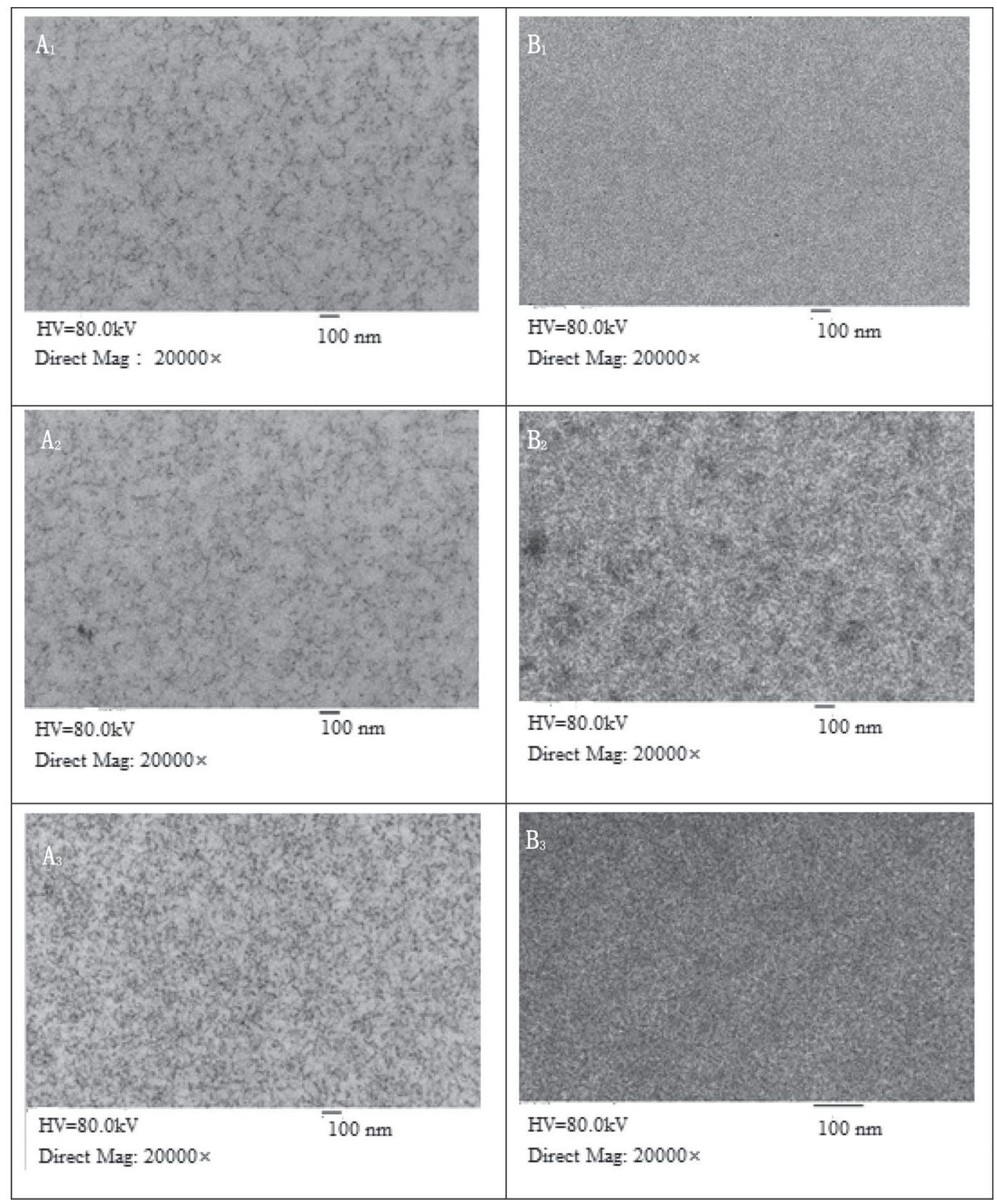

Figure 6. Transmission electron microscopy micrographs of control and radiated whey protein solutions. $\mathrm{A}_{1}: 10 \%$ whey protein solutions (WPS), control; $\mathrm{A}_{2}: 10 \%$ WPS, $15 \mathrm{kGy} ; \mathrm{A}_{3}: 10 \%$ WPS, $25 \mathrm{kGy} ; \mathrm{B}_{1}: 30 \%$ WPS, control; $\mathrm{B}_{2}: 30 \%$ WPS, $15 \mathrm{kGy} ; \mathrm{B}_{3}: 30 \%$ WPS, $25 \mathrm{kGy} . \mathrm{HV}=$ new voltage; Mag. = magnification. 
protein had a relatively smooth structure initially and aggregated particles formed after gamma radiation. Whey protein treated at both 15 and $25 \mathrm{kGy}$ showed larger particles and clusters in the scanning electron micrographs, especially for samples treated at $25 \mathrm{kGy}$. These are in good agreement with SDS-PAGE data and confirmed an aggregation of whey proteins after gamma radiation. The aggregation phenomena can be visualized via scanning electron microscopy; however, it is difficult to evaluate the changes in the internal structure. Transmission electron microscopy was used when measuring the pore size of the structures and the results are shown in Figure 6. Larger pores can be seen in control samples and denser particle clusters were observed for samples after gamma radiation treatment.

\section{CONCLUSIONS}

Gamma radiation can be used to inactivate aerobic bacteria, yeasts, and molds effectively in the whey protein model system. Application of gamma radiation altered the physicochemical and structural properties of whey proteins. Protein-protein interactions occurred after the gamma radiation treatment, which was seen in the increased viscosity and turbidity of the solutions and decreased nitrogen solubility. The aggregation of whey proteins was also confirmed by SDS-PAGE and the scanning and transmission electron micrographs. Reducing SDS-PAGE suggested a role of disulfide bonds in the whey protein cross-linking process.

\section{ACKNOWLEDGMENTS}

The financial support for this project was provided by USDA-NIFA Hatch (Washington, DC).

\section{REFERENCES}

Abu, J. O., K. Muller, K. G. Duodu, and A. Minnaar. 2006. Gamma irradiation of cowpea (Vigna unguiculata L. Walp) flours and pastes: Effects on functional, thermal and molecular properties of isolated proteins. Food Chem. 95:138-147.

Agúndez-Arvizu, Z., M. V. Fernández-Ramírez, M. E. Arce-Corrales, E. Cruz-Zaragoza, R. Meléndrez, V. Chernov, and M. BarbozaFlores. 2006. Gamma radiation effects on commercial Mexican bread making wheat flour. Nucl. Instrum. Methods Phys. Res. 245:455-458

Alighourchi, H., M. Barzegar, and S. Abbasi. 2008. Effect of gamma irradiation on the stability of anthocyanins and shelf-life of various pomegranate juices. Food Chem. 110:1036-1040.

Atlay, R. D., and C. Alfred. 2004. Effect of combined treatments on viscosity of whey dispersions. Radiat. Phys. Chem. 71:105-108.

Camp, J. V., W. Messens, A. Jérôme Clément, and A. Huyghebaert. 1997. Influence of $\mathrm{pH}$ and calcium chloride on the high-pressureinduced aggregation of a whey protein concentrate. Food Chem. 60:417-424.
Chatterton, D. E. W., G. Smithers, P. Roupas, and A. Brodkorb. 2006. Bioactivity of $\beta$-lactoglobulin and $\alpha$-lactalbumin-Technological implications for processing. Int. Dairy J. 16:1229-1240.

Chawla, S. P., R. Chander, and A. Sharma. 2009. Antioxidant properties of Maillard reaction products obtained by gamma-gamma radiation of whey proteins. Food Chem. 116:122-128.

Cieśla, K., S. Salmieri, M. Lacroix, and C. L. Tien. 2004. Gamma irradiation influence on physical properties of milk proteins. Radiat. Phys. Chem. 71:95-99.

Demicheli, M. C., B. S. Reis, A. M. Goes, and A. S. de Andrade. 2006. Paracoccidioides brasiliensis: Attenuation of yeast cells by gamma irradiation. Mycoses 49:184-189.

Esteves, M. P., A. Raymundo, I. D. Sousa, M. E. Andrade, and J. Empis. 2002. Rheological behaviour of white pepper gels-A new method for studying the effect of irradiation. Radiat. Phys. Chem. 64:323-329.

FAO/IAEA/WHO. 1980. Wholesomeness of irradiated food. Joint FAO/IAEA/WHO Expert Committee, Geneva, Oct. 27 to Nov. 3,1980 .

Foegeding, E. A., J. P. Davis, D. Doucet, and M. K. Mcguffey. 2002. Advances in modifying and understanding whey protein functionality. Trends Food Sci. Technol. 13:151-159.

Guo, M. R., P. F. Fox, and A. Flynn. 1995. Susceptibility of $\beta$-lactoglobulln and sodium caseinate to proteolysis by pepsin and trypsin. J. Dairy Sci. 78:2336-2344.

Havea, P., A. J. Carr, and L. K. Creamer. 2004. The roles of disulphide and non-covalent bonding in the functional properties of heat-induced whey protein gels. J. Dairy Res. 71:330-339.

Hendricks, G. M., and N. Hadley. 1983. Structure of the cuticle of the common house cricket with reference to the location of lipids. Tissue Cell 15:761-779.

IDF. 1964. Determination of the protein content of processed cheese products. 25. International Dairy Federation, Brussels, Belgium.

Ju, Z. Y., and A. Kilara. 1998. Gelation of hydrolysates of a whey protein isolate induced by heat, protease, salts and acid. Int. Dairy J. 8:303-309.

Ju, Z. Y., J. Otte, M. Zakora, and K. B. Qvist. 1997. Enzyme-induced gelation of whey proteins: Effect of protein denaturation. Int. Dairy J. 7:71-78.

Kasera, R., A. B. Singh, R. Kumar, S. Lavasa, K. N. Prasad, and N. Arora. 2012. Effect of thermal processing and $\gamma$-irradiation on allergenicity of legume proteins. Food Chem. Toxicol. 50:3456-3461.

Keim, S., and J. Hinrichs. 2004. Influence of stabilizing bonds on the texture properties of high-pressure-induced whey protein gels. Int. Dairy J. 14:355-363.

Langton, M., and A. M. Hermansson. 1996. Image analysis of particulate whey protein gels. Food Hydrocoll. 10:179-191.

Lee, J. W., J. H. Kim, H. S. Yook, K. O. Kang, S. Y. Lee, H. J. Hwang, and M. W. Byun. 2001. Effects of gamma radiation on the allergenic and antigenic properties of milk proteins. J. Food Prot. 64:272-276.

Lee, J. W., H. S. Yook, K. H. Lee, J. H. Kim, W. J. Kim, and M. W. Byun. 2000. Conformational changes of myosin by gamma irradiation. Radiat. Phys. Chem. 58:271-277.

Lee, S., S. Lee, and K. B. Song. 2003. Effect of gamma-irradiation on the physicochemical properties of porcine and bovine blood plasma proteins. Food Chem. 82:521-526.

Liu, X. D., R. X. Han, H. Yun, K. C. Jung, D. I. Jin, B. D. Lee, T. S. Min, and C. Jo. 2009. Effect of irradiation on foaming properties of egg white proteins. Poult. Sci. 88:2435-2441.

Mcparland, B. J. 2010. Biological Effects of Ionizing Radiation. Springer, London, UK.

Mezgheni, E., A. Giuseppe D'Aprano, and M. Lacroix. 1998. Formation of sterilized edible films based on caseinates: Effects of calcium and plasticizers. J. Agric. Food Chem. 46:318-324.

Oliveira, C. L., H. L. De, J. C. Silva, I. L. Torriani, and F. M. Netto. 2007. Effects of gamma radiation on beta-lactoglobulin: oligomerization and aggregation. Biopolymers 85:284-294.

Ouattara, B., L. T. Canh, C. Vachon, M. A. Mateescu, and M. Lacroix. 2002. Use of $\gamma$-radiation cross-linking to improve the water 
vapor permeability and the chemical stability of milk protein films. Radiat. Phys. Chem. 63:821-825.

Prakash, A., A. R. Guner, F. Caporaso, and D. M. Foley. 2010. Effect of low-dose gamma irradiation on the shelf life and quality characteristics of cut romaine lettuce packaged under modified atmosphere. J. Food Sci. 65:549-553.

Sabato, S. F., and M. Lacroix. 2002. Radiation effects on viscosimetry of protein based solutions. Radiat. Phys. Chem. 63:357-359.

Schokker, E. P., H. Singh, and D. N. Pinder. 1999. Characterization of intermediates formed during heat-induced aggregation of ß-lactoglobulin AB at neutral pH. Int. Dairy J. 9:791-800.

Shen, X., S. Shao, and M. Guo. 2017. Ultrasound-induced changes in physical and functional properties of whey proteins. Int. J. Food Sci. Technol. 52:381-388.

Silva, H. A., R. Mendes, M. L. Nunes, and J. Empis. 2006. Protein changes after irradiation and ice storage of horse mackerel (Trachurus trachurus). Eur. Food Res. Technol. 224:83-90.
Standardization Administration of the People's Republic of China. 2016. National food safety standard food protein determination (GB 5009.5-2016). Accessed Dec. 23, 2016. http://bz.cfsa.net.cn/ staticPages/5E70A48D-06EF-413A-A1D9-24F5ECD5DA7E.html.

Tsiotsias, A., I. Savvaidis, A. Vassila, M. Kontominas, and P. Kotzekidou. 2002. Control of Listeria monocytogenes by low-dose irradiation in combination with refrigeration in the soft whey cheese 'Anthotyros'. Food Microbiol. 19:117-126.

Zayas, J. F. 1997. Functionality of Proteins in Food. Springer, Berlin, Germany.

Zhang, T., J. Mccarthy, G. Wang, Y. Liu, and M. Guo. 2015. Physiochemical properties, microstructure, and probiotic survivability of nonfat goats' milk yogurt using heat-treated whey protein concentrate as fat replacer. J. Food Sci. 80:M788-794. 